\title{
MEDIA AND CULTURAL HERITAGE
}

\author{
Inge Hutagalung \\ Postgraduate Programme of Communication Universitas Mercu Buana, Jakarta, Indonesia \\ Email: inge_hutagalung@yahoo.com
}

\begin{abstract}
In general, media coverage can have a strong influence on the reputation of a cultural heritage. Media coverage often has an effect on a cultural heritage's reputation when 'good' or 'bad' news is reported. This amplifying effect has often been studied through the lens of agenda setting theory. The hypothesis behind the theory is that the frequency with the media report on an issue determines that issues' salience in the minds of the general public. In other words, the media may not be successful often time in telling people what to think, but it is stunningly successful in telling its readers what to think about. The news media 'set' the public agenda.

Since people cannot possibly attend no to every little detail about the cultural heritage around them, setting in communication is important because it helps shape the perspectives through which people see all cultural heritage in the world. In generating good news coverage about a cultural heritage, communicating with the media is one of important activities that should be maintained between communication professionals (in cultural heritage) with journalists.
\end{abstract}

Keywords: media coverage, agenda setting, framing news

\section{Introduction}

Cultural heritage which is culturally associated with the ancestors of the nation needs to be preserved. The preservation is aimed to protect the heritage from extinction which can be caused by natural disasters or vandalism.

In connection with the planned preservation, the existence of a cultural heritage requires publications. Publications will help to deliver information about the existence of the heritage, and also will help spread the word if the site is worth visiting. Such publications will involve both mainstream (such as newspapers, magazines, radio and television) or the social media (new media approach).

When the relationship with the media is built, it should be understood that a main idea of the relationship between the media and public arise with regard to the power or influence of the media. Namely, how information are selected before being published to the public. The processes are gatekeeping process and framing process on an information into a news story carried out by the media.

\section{The Media Conglomeration}

The mass media contributes to the formation of human perception and definition on social reality. With regard to this issue, there is a 'frame of reference' which connects the media and the public. Walter Lippmann (Protess, 1991) stated that the role of the newspaper is to give a picture of the outside world in the mind of the reader, although the presentation of the picture does not fully conform to the reality. Lippmann's main idea is that the news media is a window to the world and determines the cognitive map of the readers/individuals regarding the world.

Meanwhile, Tuchman (1978) in his book Making News confirmed that the news is not the mirror nor the reality of life, but the news is a window of the world, because the news is a product of social institutions; media workers are converting occurrences into news events. Tuchman further confirmed that the news is the result of compromise and negotiation about things that are newsworthy (newsworthiness).

The role of the media as described above will only be achieved if there is freedom of the media. When the media is not free, i.e. interference from the rulers, then the media will potentially be an instrument of political or 
economic interests of particular groups.

At present, the phenomenon of increasingly concentrated media ownership is a symptom of capitalism that occurred globally in many countries. In Australia, two media companies (owned by Packer and Ropert Murdock) control more than $70 \%$ of the print media market. In the United States of America, there are currently five media groups controlling more than $60 \%$ of the media market, namely AOL-Time Warner, Disney, Viacom, The News Corporation, and Sony Columbia. In the $\mathrm{UK}$, there are five publication groups controlling $93 \%$ of print media market. While in Indonesia, there are three groups of television media networks, namely Media Nusantara Cipta (RCTI, MNC, Global TV), Bakrie Group (TV One and ANTV), and PARA Group (TransTV and Trans7). For newspapers, there are currently 19 newspaper publishing group with a total of as many as 296 network members or $53 \%$ of the total number of newspapers in Indonesia. In other words, more than half of the publication of newspapers in Indonesia is part of the media conglomeration (Currant, 2000:92).

The phenomena of conglomeration, privatization and concentration of media ownership in the hands of several owners which is prevalent in the global scale could prevent the media in running its social function. Namely, that in addition to providing information, entertaining as well as making profit, the media is also a place for the people to exchange ideas related to an issue, to voice opinions and to provide feedback freely. The media can also criticize an issue/problem, perform and make coverage without the being 'restricted' by partisanship and the interests of the capital owners.

The fact that the media does not have the freedom due to the prevalent concentration of media ownership also has an impact on the coverage of information or events. In this context, there is a decrease in the quality of journalism as the audience tend to find it difficult to get the news in a transparent manner. This is because of facts or events that is reported are having the tendency of being 'engineered' by media institutions. Media which is included in a conglomeration, will have a reporting type similar to each other. Information will be selected and adapted to the direction of economic and political interests of media owners.

\section{Gatekeeping Process: Manifestation of Pressure in Coverage}

One of the things that need attention to understand the process of making news is that the media content is not only influenced by one factor, i.e. only media organizations, but there are other influencing factors such as political and economic power outside media organizations.

A study by Shoemaker and Reese shows that the media organization can not be separated from the influence of power from within and outside the organization. These relationships can be either negotiation, exchange or sometimes also in the form of conflict, both intangible and tangible.

Moreover, Gerbner (1969) illustrates that mass communicators are in a distressed condition. The pressures they face come from various power outside the organization, among others: (1) economic power represented by advertisers, competitors, foreign news agency, owners, an trade unions, (2) social and cultural force, represented by the political authorities and the law, experts, other institutions, (3) the interests and demands of the audiences, and (4) the provision of information and culture on an ongoing basis.

Of the illustration of powers surrounding the media organization, five relationships are formed which require closer attention to observe the effects that exist in the media organization and mass communicators, namely (1) the relationship with the community, (2) the relationships with pressure groups, (3) the relationship with the capital owners, advertisers, suppliers, (4) the relationship with the audiences, and (5) the relationship between parts of the organization.

Relationship model between the media with the public can be distinguished on the basis of the main goals of the media themselves. According to the organization theory, organizational goals are divided into two types: utilitarian organizational goals and normative organizational goals. The utilitarian organizational goals are the goals of making money, typically ignores heavily other factors such as education and social responsibility. The normative organizational goals are organizational goals that are not only about making money, but also the pursuit of a certain 
ideal values.

In addition, the realtionships between the media and public are also determined by the neutrality and partisanship of media crews. Neutral journalists will be accepted by the majority of the audience, otherwise journalists in favor of particular interest will only be accepted by the constituents. Another issue is about the profesionalism of the media crew. The media crew who understand the mission of the organization, dedicated to their tasks, always trying to improve the quality and objectivity of news, would be more preferred not only by the institutions, but also by a mass audience. Cohen (1963) devided the two roles of journalists, namely (1) neutral reporterpress, as information providers, interpreters and tools of government, (2) participant-press, as representatives of the public, critics of the government, and watchdogs. As a middle way of role dichotomy of 'neutral vs. participant', Weaver suggests three other journalist roles, namely as: interpreter, disseminator or advesary. Interpreter have the role to analyze and interpret complex questions, investigate government statements, and discuss national policies. Disseminator have the role to rapidly disseminate information to the public, and concentrate on the audience. Adversary role is against both the government and the business world. Although this role is weakened, it is still recognized.

Although people do not directly affect the organization of the media, pressure groups and interest groups do. For example pressure groups can limit what should be reported to the public/audience. In this condition, the relationships between pressure groups and interest groups will be formed against media organizations.

On the other hand, the relationship with the capital owners tends to reduce the independence of journalists. It is almost improbable for a journalist to make independent and critical coverage of the interests of capital owners and its cronies. The capital owners can affect media organizations, for example with a request to insert or remove a particular news content. In the context of this relationships, information is no more than a commodity to be traded. Consequently, all forms of production of the message can not be separated from the interests of the capital owners and political power surrounding it. The information presented to the audience is a reality that has been selected and arranged according to the ideological considerations of media institutions through editorial decisions (second-hand reality).

The same happens to the advertisers. Even for some particular media, advertisers are considered as 'heroes' associated with the source of funds for the survival of a media organization. The advertisers are usually sensitive to media content that is not in line with their messages, and also to controversial matters. Advertisers usually will also seek to encourage journalists to make news that supports their messages and negate news that is less or not supportive to their advertising messages. To dampen the 'unrest' on the advertisers' side, the media organizations usually make "self-censorship" immediately.

In simple ideas and based on the facts, media relationships is not only limited to the capital owners, advertisers, or interest groups. The public are clients and the source who have influence in media organizations. However, many studies have found that many mass communicators do not regard the public as something important. Of the many studies that have been done by taking samples of television viewers, it is learned that the public are often seen in a cynical manner as ignorant, incapable and unworthy (Altherde 1974, Elliott, 1972, Burns 1977, and Schlesinger 1978 in McQuail, 2005). The media determine what they want, not what the people want.

Of the illustration of five media relationships above, it appears that media organizations are in a position of attraction with the power that exist around the media organization itself, such as the economic and socio-cultural power in making news where there is a tendency for the media in favor of economic and political power of media owners.

\section{Selective Exposure: Eastern and Western Perspectives}

Today, the remarkable developments in the field of information and such advanced communication media technology, people are not just living in the era of communication revolution, but are also experiencing what is referred to as the era of communicative abundance or cornucopias of communication (Neuman, 1991; John Keane, 1998).

Communicative abundance or cornucopias of communication makes individuals have many 
opportunities to make choices and rejection of the information in accordance with selfcognition. Communicative abundance has also become a trigger of changes in information consumption patterns which is previously passive, waiting in front of the television screen, radio, or read newspapers delivered by deliveryman, into the audience who are actively seeking for information by using Google or Yahoo search engine, or the remote control of television. Individuals become active creatures in selecting and processing information in accordance with their interests and needs. Individuals are no longer be passive beings in receiving information, individuals are active in finding and rejecting an information instead.

Terminology in which an individual determines his choice of a news or information is called selective exposure. Selective exposure can simply be defined as an effort of a person (individual) to favor the desired information and avoid the unwanted one. Availability of information is abundant, and the individual will select and choose the information to be accessed and not be accessed.

With regard to the process of selective exposure, there is a difference between the West and the East. According to Lawrence Kincaid (Littlejohn, 2002), there are four distinctions in communication from the perspective of the West and the East. Firstly, the East perspective tends to focus on the aspects of unity and wholeness, whereas the West tends to look at the units or parts, and does not integrate it in a unity. Secondly, the East perspective emphasises on emotional and spiritual unification, and views the results of communication as a natural and unplanned consequences. Whilst, the West perspective, especially the United States of America, is dominated by the vision of individualism, full of planning, and schedule. Western perspective assumes that individuals actively try to achieve personal goals. Thirdly, the East perspective, verbal symbols tend to have a reduced role, and viewed with skepticism. Western style rationality also tends to not be trusted in the Eastern tradition. What is taken into account in many Asian nations philosophy is intuitive view obtained from direct experience. The thought patterns tend to be convoluted. Meanwhile, another characteristic of Western perspectives is dominated by the language. The way of thinking is linear, with a cognitive approach. Fourthly, the East perspective views relationships in society as more complicated, because it related to the social position of the role, status, and power. The Western perspective views relationships as rather not complicated, namely relations exists between two or more individuals, irrespective of differences of various backgrounds and levels.

Young Yun Kim in his article titled "Intercultural Personhood - An Integration of Eastern and Western Perspectives" (1994), and Jiafei Yin in "Beyond The Four Theories of The Press: A New Model for The Asian and The World Press" (2008), explained that the distinctive perspectives of East and West communication due to differences in the concept of the universe, knowledge, and time is the fundamental basis for how people act and behave, including the way people communicate the concepts they believed in.

In the Western perspective, the universe is seen as something that is externally created and controlled by the Supernatural power. The West view the relationship between the creation (the universe) and the creator as separate entities. The West view that the universe is not a living material, but the elementary particles that is interrelated with one another in a predictable pattern. The characteristics of the West on the universe are dualistic, materialistic and lifeless.

Whereas the East view the universe as more holistic, dynamic and the inherent to the spiritual dimension. In the East, it is believed that the universe entity is very vast, multidimensional, living organisms are consist of many parts and power interdependent with one another. For the East, the universe is a consciousness and wrapped in a continuum of His creation. The pattern formed is selfcontained and self-organizing which asserts that the universe is a manifestation of the living force of the Supernatural power. All the power of life is inseparable from human and its existence. The East view that everything in the world is impermanent.

From the above description, it is illustrated that the West and the East are not only have differences in structure but also in the content of cognition, which resulted in differences in cultural values in the society as well as communication perspective. Namely, Western societies tend to form an individualistic culture that prioritizes the personal values in the development of self-concept and process of communication. Meanwhile, Eastern societies are the opposite. 


\section{Conclusion}

It is undeniable that the mass media have a role of mediation between objective social realities and personal experience. That is, the mass media are often among the recipients with parts of other experiences that are beyond perception and direct contact of the recipients. The mass media also often provide information to shape the audiences' perceptions, the mass media can also be a link between the beauty of the world heritage with the public through travel article.

The phenomenon that is increasingly concentrated media ownership is a symptom of capitalism that occurred globally in many countries. The concentration of media ownership has made the media tends to lose its independence due to the intervention of the capital owners through media networks. Consequently, all forms of message production can not be separated from the interests of media owners. The information presented to the audience is a reality that has been selected and arranged according to ideological considerations of media institutions. These conditions describe a weak bargaining power of journalists when dealing with the interests of media owners. Unequal relationships also make journalists being understood as workers and not as media professionals.

Today, the people are not only living in the era of communicative abundance. Communicative abundance or cornucopias of communication makes individuals have many opportunities to make choices and rejection of information in accordance with the self-cognition. Individuals become active creatures in selecting and processing information in accordance with their interests and needs. Individuals are no longer be passive beings in receiving information, individuals are instead active in finding and rejecting an information.
Therefore, in delivering cultural heritage news, media professionals are expected to understand the cultural context (east and west) and the media organization's ideology in addition to realizing the media owners' interest in news coverage and also realizing the proactive information selection process of the audience.

\section{References}

Curran, James. (2000). Mass Media and Democracy: A Reappraisal dalam James Curran dan Michael Gurevitch (ed), Mass Media and Society, third edition. London: Arnold Publications.

John Keane, Times Literary Supplement, 28 August 1998, 14-16.

Littlejohn, Stephen W. (2002). Theories of Human Communication, Seventh Edition, Belmont, California: Wardsworth/Thomas Learning.

McQuail, Dennis. (2005). Media Performance: Mass Communication and Public Interest. London: Sage Publications.

Mosco, Vincent. (2009). The Political Economy of Communication, 2nd edition. London: Sage Publications.

Murdoch, Graham. \& Golding, Peter. (2000). Political Economy of The Media. London: Routledge.

Neuman, W. R. (1991). The Future of The Mass Audience. New York: Cambridge University Press.

Protess, David L. \& Maxwell McCombs. (1991). Agenda Setting: Readings on Media, Public Opinion, and Policymaking. New Jersey: Lawrence Erlbaum Associates, Inc.

Severin, Tankard. \& James W. Tankard. (2001). Communication Theories: Origins, Methods and Uses in The Mass Media. New York: Longman.

Tuchman, G. (1978). Making News: A Study of The Construction of Reality. New York: Free Press. 